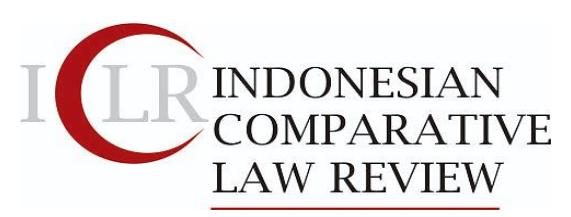

Volume 2 No 1, December 2019 P-ISSN: 2655-2353, E-ISSN: 2655-6545
Article Info:

Received : 20-01-2020

Revised : 18-05-2020

Accepted : 30-05-2020

\section{A Comparative Legal Studies of Abortion Policies In Indonesia, Malaysia and England}

Nur Ras Firzaa

International Islamic University Malaysia, Malaysia

Email:rfirzaa97@gmail.com

\begin{abstract}
This paper aims to address abortion from the perspective of Malaysian law, Indonesian law, English law and Islamic Jurisprudence. It will look into the three national laws to extricate ruling in regards to abortion and simultaneously making an effort to have knowledge on the ruling of abortion taking into consideration of Islamic Jurisprudence mentioned by the highest source of Islamic law (The Holy Book of Al-Quran), scholars and jurists. This paper also critically discussed the law cases that had been decided by courts in each jurisprudence in order to understand more on the law of abortion and this followed by comparing the three laws to identify the similarities and dissimilarities between these jurisdictions. The paper had reached some fundamental outcome which are: Malaysian law and Indonesian law impede abortion except in case of necessity and when there are reasonable justifications however, English law provides that abortion can be done if the fetus is less than 24 weeks of pregnancy. In addition, the scholars are in consensus that abortion is prohibit when the fetus starts to breath.
\end{abstract}

Keywords: Abortion; Malaysian law; Indonesian law; English law; Islamic jurisprudence.

\section{Introduction}

Generally, abortion means the termination of a pregnancy before the fetus is viable or able to survive outside the uterus. The Oxford Dictionary of Law defines abortion as the termination of a pregnancy or premature expulsion of a fetus from the womb before the normal period of gestation is complete. ${ }^{1}$ There are two types of abortion which are spontaneous or induced. ${ }^{2} \mathrm{~A}$ spontaneous abortion (miscarriage) occurs naturally without interference. Meanwhile an induced abortion is one that is caused by artificial means such as medications and surgical procedures. According to the World Health Organization $(\mathrm{WHO})^{3}$, an estimated 25 million unsafe abortions occur each year throughout the whole world. The fact that women seek for unsafe abortions mainly because of the lack of knowledge in their respective countries' laws and policies on abortion. Hence, this paper will identify three jurisdictions for pregnant women to have the

1 Law, Jonathan, and Elizabeth A. Martin. "Oxford A Dictionary of Law (7 Ed.)." Oxford Reference. Oxford University Press, 2009. https:/ / www.oxfordreference.com/view/10.1093/acref/978019 9551248.001.0001/acref-9780199551248-e-

7?rskey $=7 \mathrm{zLjHJ} \&$ result $=8$.

2 Das, Sunil Kumar. "The moral issues of abortion ongoing debates." (2012).

3 WHO: Unsafe abortion: global and regional estimates of the incidence of unsafe abortion and associated mortality in 2008. 6th edition. Geneva: World Health Organization; 2011 
understanding of terminating their fetus miscarriage is done voluntarily and with the based on the laws and the Islamic contexts.

\section{Analysis and Results}

\subsection{The laws in Malaysia}

The first legal issue is whether women in Malaysia can have a legal abortion. Abortion is recognized as causing miscarriage in the Penal Code. The most relevant provisions to be discussed are Section 312 until Section 316 of the Penal Code. Section 312 of the Penal Code states, "whoever voluntarily causes a woman with child to miscarry shall be punished with imprisonment for a term which may extend to three years or with fine or with both; and if the woman is quick with child, shall be punished with imprisonment for a term which may extend to seven years, and shall also be liable to fine". It can be inferred that under this section, abortion or causing miscarriage is illegal and it is an offence. However, certain exceptions are provided in the section.

This provision specifically deals with consent of the woman. If the woman with child consents for the abortion, this section is applicable. This is because, the word "voluntarily" means that the woman consents for the abortion. In the explanation of the section, it is clearly stated that "a woman who causes herself to miscarry is within the meaning of this section". There are two limbs that can be found under this section namely causing miscarriage to a woman pregnant with child and woman quick with child. The punishment for both aforementioned situations is different. The former is subjected to three years of imprisonment or fine, while the latter is subjected to seven years of imprisonment or fine.

To determine whether a person had committed an offence under this section is by fulfilling the elements of the provision. The first element that has to be fulfilled is that the consent of the woman with child. The next element is that the act of causing miscarriage must be done with the absence of good faith to save the life of the pregnant woman, or to prevent injury to the mental or physical health of the pregnant woman which is greater than if the pregnancy were terminated. If both of the elements are satisfied and fulfilled, a person that causes miscarriage to a woman with child will be liable for the offence of causing miscarriage.

There are few exceptions laid down under Section 312 of the Penal Code. The first exception that has to be fulfilled in order to have a valid miscarriage is that it must be done by a registered medical practitioner under Medical Act 1971. Next, the miscarriage must be necessary to be carried out and the act of causing miscarriage has to be done in good faith to save the life of the woman with child. The criteria in determining whether it is done in good faith or otherwise can be cross referred to Section 52 of Penal Code. Section 52 of the Penal Code provides that "good faith" is there when the act is done on the basis of due care and attention. The other exception to be fulfilled in order to have a valid miscarriage is the miscarriage was done as the risk of continuing the pregnancy will endanger the life of the pregnant woman or could cause injury to mental health of the pregnant woman or could cause injury to physical health of the pregnant woman and those risks mentioned have to be greater if there is no termination of pregnancy done. To determine whether the miscarriage is valid, all of the exceptions as mentioned above are to be fulfilled.

Some cases to further illustrate the position of abortion in Malaysia can be seen in the case Munah bt Ali $v$ PP. ${ }^{4}$ In this case, the defendant was charged under Section 312 of the Penal Code for voluntary causing a

\footnotetext{
4 [1958] 1 MLJ 159
} 
female Chinese woman to miscarry and such thought and not taken enough steps to miscarriage was not proven not done in good examine the woman further. The defendant faith for the purpose of saving the life of the was sentenced to a fine of RM 3, 500 in woman. However, there was evidence to default four months' imprisonment. From show that although there was an insertion of this case, we can infer that it is presumed that an instrument into the woman's vagina the doctor that is going to perform abortion causing her to hemorrhage, the woman was to the woman will be done in good faith. This proven not to be pregnant at the time the act is because the abortion will be done with due of causing miscarriage was done. This means care and attention as the continuation of that the requirements of Section 312 of the pregnancy will cause serious psychological Penal Code are not fulfilled. Hence, a new and physical problem. Hence, it is necessary charge was framed against the defendant to terminate the child if continuation of which was attempt to cause miscarriage pregnancy gives greater risk to the pregnant contrary to Section 312 and 511 of the Penal woman and it will endanger her life. Code. The court held that the accused is only However, it needs to be noted that abortion liable for attempt to cause miscarriage and need to be done in good faith as to save not miscarriage as the victim was not a mother's life and it is done by a registered woman with child and there was an absence of the element of 'woman with child'. Hence in accordance to the explanation above, if a woman is considered to be a woman with child, she can be held liable for causing miscarriage but she will not be liable for causing miscarriage or abortion if all the exceptions are proven.

In another case of Public Prosecutor $v$ Dr Nadason Kanalingam 5 where an obstetrician and gynecologist was charged under Section 312 of the Penal Code for voluntarily causing a woman with child to miscarry and the act of causing miscarriage was found to be done without good faith to save her life. Although the woman had tubal ligation done on her by the defendant, she was found to be fourteen weeks pregnant. As she had enlarged varicose veins, the defendant injected her with $150 \mathrm{cc}$ saline. She was in labor within 48 hours and a male fetus was aborted. The defendant claimed that he performed the operation in good faith for the purpose of saving the life of the woman. However, from the evidence adduced Court, the judge held that abortion was not done in good faith as it was to cover up his act of negligence in vasectomy operation and the defendant had not given any reasonable medical practitioner under Medical Act 1971.

According to Bourne ${ }^{6}$, where a surgeon of highest skill, openly, in one of the London Hospitals, without fee, performed the operation of abortion to a young girl who was pregnant as the result of rape. Later, he was charged under the Offences against the Person Act 1861 with unlawfully procuring abortion of the girl. The jury were directed that it was for the prosecution to prove beyond reasonable doubt that the operation was performed in good faith for the purpose of only preserving the girl's life. The surgeon did not wait until the patient was in peril of immediate death, but it was his duty to perform the operation if on reasonable grounds, and with adequate knowledge, he was opinion that the probable consequence of the continuance of pregnancy would be make the patient a physical and mental wreck. Therefore, the surgeon was not liable in conducting abortion to the young girl as the court was satisfied that the operation was done in good faith. Nevertheless, from this case, if the continuation of the pregnancy would cause serious psychological problems to her and it will endanger her life, she could undergo the abortion to save her life. They need to prove that the risk of experiencing 
serious psychological problems must be Code that relates to abortion is Section 316. greater if there is no termination of This section provides that causing death of a pregnancy.

Next, Section 313 covers causing miscarriage without the woman's consent. The section provides that whoever commits the offence defined in section 312, without the consent of the woman, whether the woman is quick with child or not, shall be punished with imprisonment for a term which may extend to twenty years, and shall also be liable to fine. Here, the punishment is much more severe due to the fact of not getting any consent from the mother of the child.

Section 314 states the situations where the intention to cause miscarriage eventually causes death of the mother. The punishment is more severe if the medical practitioner did not receive any consent from the mother which is imprisonment for a term which may extend to twenty years. While with consent they are liable with imprisonment for a term which may extend to ten years and shall also be liable to fine. It should be noted that the section further explain that it is not essential that the offender should know that the act is likely to cause death. In the case of Ong Bak Hin $v$ The General Medical Council 7, a registered medical practitioner performed an abortion procedure on a woman that later caused her death. He was charged under Section 314 and sentenced to five years of imprisonment.

The next relevant provision is Section 315 which deals with the act that was done with the intention to prevent a child being born alive or to cause it to die after birth. Nonetheless, it needs to be noted that this section would not be applicable if the act is done in good faith for the reason to save the life of the mother. ${ }^{8}$ The last section in Penal

\footnotetext{
7 [1956] 2 All ER 257

8 Kassim, Puteri Nemie Jahn. Law and Ethics Relating to Medical Profession. International Law Book Services, 2010.
} quick unborn child by an act amounts to culpable homicide. The illustration of this section gave a sight that if a person has the intention to cause death of a pregnant woman but only injured the woman and cause the death of the unborn child which she is pregnant at that time, then that person shall be liable under this section.

\subsubsection{Definition of 'quick with child'}

Nowhere in the Penal Code mentions the meaning and definition of quickening of child. The definition of quickening of child is important in determining the punishment suitable for the offender if it was found that the miscarriage is done and it is proved to be an offence. The definition of the phrase "quick with child" is explained in the case of $\boldsymbol{M} \mathcal{E} \boldsymbol{M}$, where the court held that the definition of quick with child is sensations experienced by a woman about the 4 th or 5 th month of pregnancy. The symptoms are ascribed to the first perception of movements of the fetus.

\subsubsection{Right of a fetus}

According to the case of Chin Yoke Teng $v$ William Ui Ye Mein ${ }^{9}$, the Court of Appeal held that an unborn child or fetus is biologically distinct organism from the mother. It is not a legal person and it has been accepted that in order to have a right of action, the fetus must be born and be a child. When an unborn child becomes a living person and suffers damage as a result of prenatal injuries, then only the child is able to bring proceedings. On birth, the child acquires legal status and thus, legal rights. In other words, the fetus that does not has rights to an action and since it is a biologically distinct organism from the mother, hence, the mother can have a legal abortion and the miscarriage done would not amount to an offence.

\footnotetext{
9 [2005] 2 MLJ 480
} 


\subsubsection{Paternal rights in abortion}

In the case of Paton $v$ Trustees of British Advisory Services 10, plaintiff (husband) sought an injunction to restraint the wife from having an abortion. The wife had obtained the required certificates from two doctors that she satisfies one of the statutory grounds but the plaintiff alleged that she was acting in bad faith. The plaintiff needed to establish that he had locus standi to bring his action. The High Court held that a husband does not have any legal right enforceable at law and equity to stop his wife from having abortion or to stop doctors from carrying out a legal abortion. To strengthen this issue, the case of Planned Parenthood of Central Missouri v. Danforth, ${ }^{11}$ the Supreme Court has found laws requiring a spouse's consent for an abortion to be unconstitutional. The Court reasoned that a husband's refusal to consent would in effect veto a woman's choice to terminate a pregnancy. While both prospective fathers and pregnant women have an interest in the decision, when the two disagree, only one partner's position can prevail. According to the Court, since the woman actually carries the pregnancy, 'the balance weighs in her favor,' preventing the husband from vetoing her choice.

\subsection{The laws in England}

In 1861, the new Offences Against the Person Act 1861 was enacted. This Act is the foundation upon the later Acts in regards of abortion. There are two relevant provisions in this act, Section 58 and 59. Section 58 provides that the use of any means by a woman, with intent to affect her own miscarriage, if actually pregnant, or by others with like intent without regard to whether she was actually pregnant or not, to be a felony, punishable by imprisonment from three years to life even when performed for

10 [1979] QB 276

11428 U.S. 52 (1976) medical reasons. ${ }^{12}$ Section 59 provides that the furnishing of any means affecting abortion with knowledge that it was intended to be used for such purpose on any woman, pregnant or not, to be a misdemeanor, whether the pregnancy is actual or imaginary. This Act makes no exception for therapeutic abortion and provide no difference in available sentence between a woman who self-induces her own miscarriage and a third-party abortionist.

While the Offences Against the Person Act 1861 makes no distinction between abortions early and late in pregnancy, a second statute, the Infant Life (Preservation) Act 1929 was enacted. Section 1(1) and (2) provides the punishment for child destruction.

What can be inferred from the above provisions is that this Act prohibits the intentional destruction of 'the life of a child capable of being born alive before it has an existence independent of its mother', unless this is done 'in good faith for the purpose only of preserving the life of the mother'. The statute was not intended to regulate abortions but rather to close a legal loophole whereby someone who killed a baby during the process of spontaneous birth would commit neither the offence of unlawful procurement of miscarriage nor murder, if the child did not yet have an existence independent of the mother and was thus not yet 'a person in being'. Meanwhile subsection 2 states that the age of which a fetus must be presumed to be viable is 28 weeks. Hence, this Act supplies medical practitioner the power to decide when abortion is legal in cases when the life of the mother is being threatened.

The case that can illustrate this Act is $\boldsymbol{R}$

\footnotetext{
12 Veitch, Edward, and Richard RS Tracey.

"Abortion in the common law world." The American journal of comparative law (1974): 652696
} 
$v$ Bourne $^{13}$. In this case a young girl, 15 years of age, was pregnant as the result of rape. A surgeon openly, in one of the London hospitals performed the operation of abortion with the consent of the girl's parents. He was charged under section 58 of the Offences Against the Person Act 1861 with unlawfully procuring the abortion of the girl. He defended himself on the grounds that the girl's mental and physical health might suffered if the pregnancy continued. The court held that it was for the prosecution to prove beyond reasonable doubt that the operation was not performed in good faith for the purpose only of preserving the life of the girl. The surgeon had not got to wait until the patient was in peril of immediate death, but it was his duty to perform the operation if, on reasonable grounds and with adequate knowledge, he was of the opinion that the probable consequence of the continuance of the pregnancy would be to make the patient a physical and mental wreck. Hence, he was found not guilty.

Finally, the Abortion Act 1967, carves out a detailed therapeutic exception to prosecution for offences relating to abortion. This Act did not invalidate 1861 and 1929 Acts but created statutory defenses to the crimes of procuring a miscarriage and destroying a fetus. In its current form, the Act, Section 1(1) (a) until (d) provides that it is requires the procedure to be performed by a registered medical practitioner, and only if two registered medical practitioners form an opinion in good faith that the pregnancy has not exceeded its twenty-fourth week and that the continuation of the pregnancy would involve a risk to the physical or mental health of the pregnant woman or any of her existing children. There is no time limit for an abortion if there is a substantial risk that, if the child were born, it would suffer from physical or mental abnormalities that would result in a serious handicap, if the abortion would prevent grave permanent injury to the

13 [1939] 1 KB 687 physical or mental health of the pregnant woman, or if the continuation of the pregnancy would involve risk to the life of the pregnant woman. In these instances, two medical practitioners must agree that these circumstances exist. ${ }^{14}$

The Act thus recognizes an important role for doctors as gatekeepers to abortion services. In addition to placing limitations on who may authorize and perform procedures, the Act restricts the locations in which they may be offered and sets out notification requirements to certify their opinion that there is lawful reason to terminate the pregnancy. The abortion procedure must take place in a hospital or other place approved by the Secretary of State such as at the National Health Service (NHS) Hospital or British Pregnancy Advisory Service Clinic. Registered medical practitioners may also terminate pregnancies without an additional opinion of another practitioner in emergency situations. An emergency situation exists where the medical practitioner believes, in good faith, that the termination is immediately necessary to save the life or prevent permanent, grave injury to the physical or mental health of the pregnant woman ${ }^{15}$.

14 United Kingdom. Sexual Health Policy Team. Department of Health. Guidance in Relation to Requirements of the Abortion Act 1967 for All Those Responsible for Commissioning, Providing and Managing Service Provision. By Sexual Health Policy

Team, Public Health Directorate 10250. May 2014.

Accessed August 4, 2019.

https://assets.publishing.service.gov.uk/govern ment/uploads/system/uploads/attachment_dat a/file/313459/20140509_-

_Abortion_Guidance_Document.pdf.

15 United Kingdom. British Pregnancy Advisory

Service. Britain's Abortion Law What It Says, and

Why. By Jennie Bristow, Alan Naftalin, Ellie Lee, and Sally Sheldon. Accessed August 4, 2019. http://www.reproductivereview.org/images/up loads/Britains_abortion_law.pdf. 
In the case of $\boldsymbol{R} v$ Smith $^{16}$, Dr. Smith psychologist explained in his report she was was a General Practitioner with a private in a state of shock and that she had lost touch practice in abortion services. A woman of 19 with her feelings. The legislators when they was referred to him seeking a termination come to enact legislation must have due and Dr. Smith spent a little under 15 minutes regard to the mother's right to life. The court with her. He asked her why she didn't want held that surgical intervention which has the to continue with the pregnancy and she effect of terminating pregnancy bona fide responded that she was not in love with the undertaken to save the life of the mother father and that she was scared of childbirth. where she is in danger of death is Dr. Smith did not perform any medical tests, permissible. The danger has to represent a he did not ask about her medical history, and substantial risk to her life. The law does not he did not conduct an internal examination of require the doctors to wait until the mother is the woman. He told her that if she could give in peril of immediate death.

him $£ 150$ in cash on that day, he could perform the termination the following morning. The woman replied that it would take her a while to get the money together and Dr. Smith booked her in for a termination the following week. The doctor was found liable for performing an unlawful abortion because the element of good faith was found to be absent. He had made no internal examination of the patient, had taken no steps in inquiring into her personal history and situation and there are only the doctor's notes stated the grounds for termination of pregnancy, "depressed." There is also no evidence that the doctor who had given the second opinion had examined the patient. Therefore, Dr. Smith was liable under Abortion Act 1967.

The next case that deliberates this issue is Attorney General $v X$ and Others ${ }^{17}$. The first defendant, a fourteen years old school girl, discovered that she was pregnant as the result of an alleged rape. The girl and her parents concluded that the best course to adopt in relation to the girl's circumstances was to travel to England and obtain an abortion there. Then, Attorney General obtained interim injunctions in the High Court restraining the girl and her parents from interfering with the right to life of the unborn. When she learned she was pregnant she had wanted to kill herself. The

\subsection{The laws in Indonesia}

In Indonesia abortion is prohibited in Indonesian Medical Ethics Code and Indonesia Penal Code, however the Health Act 2009 (replacing the Health Act 1992) covers that the abortion can be done with certain conditions. First is the Indonesia Penal Code (KUHP- Kitab Undang-undang Hukum Pidana) determines that abortion is illegal act without any exception, explained in Sections 299, 346, 347, 348 and 349. Sections 346 until 349 are under chapter XIX about The Crime on a Soul while Section 299 is under chapter XIV about Moral Crime. Abortion regulation in Indonesia Penal Code (KUHP) especially Book II about crime indicates that abortion act is a criminal without any exception. Hence, Indonesia Penal Code (KUHP) determines abortion crime tightly, but it does not give the age boundaries of the pregnancy which are prohibited to be aborted, but it differs the abortion and the murder of the infant at the time of its birth or no longer after it is born. ${ }^{18}$ (Section 341 and 342)

Next is the Health Act 2009 and the Health Act 1992. Health Act 2009 decided that the conditions of abortion are in Sections 75,76 and 77 while the criminal sanctions of the crime of the abortion conditions were

18 Tanuwijaya, Fanny. "Abortion on law and moral perspective in Indonesia." JL Pol'y $\mathcal{E}$ Globalization 28 (2014): 21. 
included in Section 194 (Imprisonment not 2.4. Comparison of Abortion in the exceeding 10 years and fine not exceeding 1 Malaysian Law, English Law and billion rupiahs). The abortion norms that Indonesian Law

were legalized in the Health Act 2009 are different from the Health Act 1992. The norms of the Health Act 2009 have wider scopes in determining the abortion acts while the Health Act 1992 determined the abortion in Section 15, it can be determined with tight requirements, which are only used to save the life of the pregnant mother and the fetus and the sanction for violating this law is in Section 80 (imprisonment not exceeding 15 years and fine not exceeding 500 million rupiahs). Basically, an abortion is forbidden in the Health Act 2009 (Section 75), but an abortion can be done if it completes those conditions: - The indication of medical emergency which is detected since the earlier pregnancy, which threaten the safety of the mother or the fetus, suffering severe genetic diseases and congenital malformations, which cannot be cured and finally make the fetus cannot alive outside the womb or a pregnancy as the impact of a rape that causes psychology trauma for the victim. There are also further requirements that were imposed by the latest the Health Act 2009. According to Section 76, abortion as explained in Section 75 only can be done: a. The age of the pregnancy is less than six weeks, counted from the first day of the last period time, except something that related with medical indication. $b$. by an expert who has competency and who is in charge and has certificate which has been legalized by Ministry. c. by the approval of the pregnant mother that is concerned in this case. $d$. by the approval of her husband, except she is the victim of a rape and e. Provider of sanitation service that fulfills the requirement which is determined by Ministry. Therefore, for a woman in Indonesia to be legally procure abortion, they need to comply with these requirements.

The law on abortion is not permitted in Malaysian law except in the case of necessity and exceptional justification such as the aim to save the life of the mother, request from a specialist doctor, pregnancy is not detrimental to the life of the pregnant woman, and the termination of fetus must be done before four month of pregnancy with the consent of the pregnant woman. Abortion in Malaysian law is prohibited based on Section 312 until Section 316 of the Malaysian Penal Code. Nevertheless, this is quite different in England as by virtue of The Abortion Act 1967 (Section 1(1)(a)(b)(c)(d)), a pregnant woman can terminate her pregnancy before 24 weeks of pregnancy. The exception to this is the termination can be carried out after 24 weeks in certain circumstances for example, mother's life is at risk or the child would be born with a severe disability that was identified by medical practitioner. The Act thus recognizes an important role for doctors as gatekeepers to abortion services. In addition to placing limitations on who may authorize and perform procedures, the Act restricts the locations in which they may be offered and sets out notification requirements to certify their opinion that there is a lawful reason to terminate the pregnancy. Be that as it may, Indonesian law provides that abortion according to Section 75 of the Health Act 2009 is prohibited, but an abortion can be the exception if: 1) Medically Indicated; 2) fetus suffered from severe genetic diseases and congenital malformations; 3 ) as an impact of the rape and terminate it before 6 weeks of the pregnancy. Generally, it can be found that the ruling on abortion and its punishment in the three jurisdictions are similar to a large extent which is if a pregnancy is detrimental in nature and harmful to the mother or the fetus hence abortion can be performed. 


\subsection{Islamic Perspective on Abortion}

Among Muslims, the permissibility of abortion depends on factors such as time and extenuating circumstances. Islam recognizes the preciousness of human life, and believes it should be protected fully because Islam upholds the sanctity of life. There is a number of Qur'anic verses which testify this such as in Surah Al- Isra', verse 70:

"And indeed We have honored the children of Adam, carried them on land and sea, gave them lawful, pure provisions, and greatly preferred them above many of those We have created."

Killing children is specifically condemned as they are the helpless victims in every society. In this regard, the Holy Book of Quran (Surah Al-Isra 17:31) says:

"You shall not kill your children due to fear of poverty. We provide for them, as well as for you. Killing them is a gross offense."

There is consensus among the Muslim jurists and scholars that induced abortion is forbidden (Haram), after the spirit is blown into the fetus. Sheikh Yusuf Al-Qardlawi, states in this regard in his well-known book, The Lawful and the Prohibited in Islam:

"While Islam permits preventing
pregnancy for valid reasons, it does not
allow doing violence to the pregnancy
once it occurs. Muslim jurists agree
unanimously that after the fetus is
completely formed and has been given a
soul, aborting it is haram. It is also a
crime, the commission of which is
prohibited to the Muslim because it
constitutes an offense against a
complete, live human being." 19

Before the breathing of the soul, it might be allowed under social necessities which are complex and different between

\footnotetext{
19 Al-Qaradawi, Yusuf. The Lawful and the Prohibited in Islam (al-halal wal haram fil Islam). American Trust Publications, 1999.
}

cultures and times, such as pregnancies resulting from extra-marital affairs, rapes and incest, pregnancies at a young age, virus infection upon the baby, fear of baby deformity and other factors. Before ensoulment, induced abortion remains a prohibited act but less serious than that performed after ensoulment, which is lawful only to save the mother's life. The position of abortion according to the Malaysia Fatwa Committee, for abortion to be carried out a fetus must be under 120 days of gestation, if the mother's life is under threat or if the fetus is abnormal. 20

\section{Conclusion}

In conclusion, abortion in Malaysian law is prohibited by the Penal Code of Malaysia. Abortion is not permitted in Malaysian law except in the case of necessity and excuse such as the aim to save the life of the mother, request from a specialist doctor, is not detrimental to the life of the pregnant woman, and must be done before four month of pregnancy with the consent of the pregnant woman. Whoever violates this law in Malaysia will be punished by imprisonment or fine. However, in England by virtue of the Abortion Act 1967 a woman can terminated her pregnancy before 24 weeks of pregnancy (length of pregnancy is calculated from the first day of the last menstruation period). Nevertheless, they can be carried out after 24 weeks in certain circumstances - for example, if the mother's life is at risk or the child would be born with a severe disability. Yet in Indonesia, it can be concluded that an abortion according to Section 75 of the Health Act 2009 is

\footnotetext{
20 Department of Islamic Development Malaysia (JAKIM). Islamic views on abortion [Malay translation]. http://www.efatwa.gov.my/artikel/pandangan-syarakmengenai-pengguguran-kandungan. Accessed August 05, 2019
} 
prohibited, but an abortion can be the References

exception if the mother is medically indicated, fetus suffered from severe genetic diseases and congenital malformations and the child is as an aftermath of a rape crime. In addition, the pregnancy can be procured before 6 weeks of the pregnancy.

In my opinion, abortion can be considered ethically moral if there are glaring reasons for why one might think abortion is the answer; for instance, imminent harm to the mother, being raped, or not having the resources to start a family. The concept of autonomy that stresses the overriding power of choice and control over oneself and the principle of beneficence ${ }^{21}$ that provides the benefits of the action are much substantial than the earlier in regards to the issue of abortion. Nonetheless, this is very much debatable. Thus, there are laws that act as a standard for people to follow. It will provide the answers to all the debate of medical ethics rather than just questions.

In spite of that as law will keep on developing and thus it is not static. The framework of law could possibly change in the near future as human perception and the society's perception of abortion. This is to be reflected in the laws created by humans. However, the issue on ethical principles such as beneficence and non- maleficent will always remain divided and debatable as every individual have their own point of view and are mainly affected by their religion. Consequently, there is a need to publish and distribute newspapers and books related to impairment caused by abortion so that people will be more conscious that it is injurious to women's health if there is no necessity to terminate the fetus. In addition, the social stigma in regards to abortion may be eliminated by improving the knowledge of public pertaining to abortion.

\section{Statutes:}

Malaysia:

Malaysian Penal Code

Medical Act 1971

England:

Offences Against Person Act 1861

Infant Life (Preservation) Act 1929

Abortion Act 1967

Indonesia:

Indonesian Medical Ethics Code

Indonesia Penal Code (Kitab Undang-undang Hukum Pidana)

Health Act 1992

Health Act 2009

Case Law

Malaysia:

Munah bt Ali v PP [1958] 1 MLJ 159

Public Prosecutor $v$ Dr Nadason Kanalingam [1985] 2 MLJ 122

Bourne (1938) 3 All ER 615

Ong Bak Hin $v$ The General Medical Council [1956] 2 All ER 257

$M \& M 278$

Chin Yoke Teng $v$ William Ui Ye Mein [2005] 2 MLJ 480

Paton $v$ Trustees of British Advisory Services [1979] QB 276

Planned Parenthood of Central Missouri $v$. Danforth 428 U.S. 52 (1976)

England:

$R v$ Bourne [1939] 1 KB 687

R v Smith [1974] All ER 376

Attorney General $v$ X and Others [1992] 1 IR 1

Books and Articles:

${ }^{21}$ Denbow, J. (2013). "Abortion: When Choice and Autonomy Conflict". Berkeley Journal of Gender, Law \& Justice 20.1: 216 
Al-Qaradawi, Y. (1999). The Lawful and the Prohibited in Islam (al-halal wal haram fil Islam). American Trust Publications.

Das, S. K. (2012). The Moral Issues of Abortion on going Debates.

Denbow, J. (2013). Abortion: When Choice and Autonomy Conflict. Berkeley Journal of Gender, Law \& Justice, 20 (1): 216

Department of Islamic Development Malaysia (JAKIM). Islamic views on abortion [Malay translation].

http://www.efatwa.gov.my/artikel/pandangansyarak-mengenai-penggugurankandungan. Accessed August 05, 2019

Kassim, P. N. J. (2010). Law and Ethics Relating to Medical Profession. International Law Book Services.

Law, Jonathan., \& Elizabeth A. M. (2009). Oxford A Dictionary of Law (7 Ed.). Oxford Reference. Oxford University Press.

https:/ / www.oxfordreference.com/vie $\mathrm{w} / 10.1093 /$ acref/9780199551248.001.00

01/acref-9780199551248-e-

7?rskey $=7 \mathrm{zLjHJ} \&$ result $=8$.

Quran (2013) translated by Abdullah Yusuf Ali. Ware, Hertfordshire: Wordsworth Editions Limited.

Tanuwijaya, F. (2014). Abortion on law and moral perspective in Indonesia. JL Pol'y \& Globalization 28: 21.

United Kingdom. Sexual Health Policy Team. Department of Health. Guidance in Relation to Requirements of the Abortion Act 1967 for All Those Responsible for Commissioning, Providing and Managing Service Provision. By Sexual Health Policy Team, Public Health Directorate 10250. May 2014. Accessed August 4, 2019.

https://assets.publishing.service.gov.u $\mathrm{k} /$ government/uploads/system/uploa ds/attachment_data/file/313459/2014
0509_-

_Abortion_Guidance_Document.pdf

United Kingdom. British Pregnancy Advisory Service. Britain's Abortion Law What It Says, and Why. By Jennie Bristow, Alan Naftalin, Ellie Lee, and Sally Sheldon. Accessed August 4, 2019. http://www.reproductivereview.org/i mages/uploads/Britains_abortion_law. pdf.

Veitch, E., \& Richard, R. S. T. (1974). Abortion in the common law world. The American journal of comparative law, 652696

WHO: Unsafe Abortion: Global and Regional Estimates of the Incidence of Unsafe Abortion and Associated Mortality in 2008. 6th edition. Geneva: World Health Organisation; 2011 